\title{
LIMITES DO CONTROLE ADMINISTRATIVO DO CONSELHO NACIONAL DE JUSTIÇA
}

\section{LIMITS OF ADMINISTRATIVE CONTROL OF THE NATIONAL COUNCIL OF JUSTICE}

\author{
Alderico Kleber de Borba ${ }^{1}$ \\ Marcos Paulo Andrade Bianchini ${ }^{2}$
}

\section{RESUMO}

O artigo tem como objetivo analisar o histórico e os limites de atuação do Conselho Nacional de Justiça-CNJ no âmbito administrativo do Poder Judiciário. Serão demonstradas as decisões do CNJ próprias do Poder Legislativo e Judiciário, acarretando notória usurpação de função. Os primeiros Conselhos de Justiça surgiram na Europa (França), na década de 50, tendo, em meados de 1980 difundido pela América Latina. No Brasil foi concretizado com Emenda Constitucional n. ${ }^{\circ}$ 45/2004. Desde então, o Supremo Tribunal Federal é constantemente acionado para deliberar sobre questões e decisões do CNJ. Na pesquisa utilizou-se os métodos dedutivo, dogmático e bibliográfico.

Palavras-Chave: Conselho Nacional de Justiça; Controle; Sanções; Decisões; Poder Judiciário.

\section{ABSTRACT}

The article aims to analyse the history and the limits of action of the National Council of Justice-CNJ under the administrative judiciary. Will be demonstrated the CNJ own of the legislature and judiciary, leading notorious usurpation of function. The first Advice of Justice arose in Europe (France), in the 50, in mid-1980 spread by Latin America. In Brazil was implemented with constitutional amendment $n^{\circ}$ 45/2004. Since then, the Supreme Court is constantly driven to deliberate on issues and decisions of the CNJ. In the survey used the deductive, dogmatic and bibliographic methods.

Keywords: National Council of Justice; Control; Sanctions; Decisions; Judiciary Power.

\footnotetext{
${ }^{1}$ Mestrando em Direito pela Fundação Municipal para Educação Comunitária - FUMEC, São Paulo (Brasil). Procurador da Câmara Municipal de São Gotardo. Advogado. E-mail: akbmp@ hotmail.com

${ }^{2}$ Mestrando em Direito pela Fundação Municipal para Educação Comunitária- FUMEC, São Paulo (Brasil). Advogado. E-mail: marcosbianchini@ hotmail.com
} 


\section{INTRODUÇÃO}

A criação dos Conselhos de Justiça se deu inicialmente na Europa, na década de 50, tendo surgido na França. Em meados de 1980 difundiu-se pela América Latina.

Em todos os Conselhos, denota-se uma composição híbrida, com representantes da sociedade civil, do Poder Judiciário e do Executivo, variando de país a país. Itália-Presidente da República que é também o presidente do Conselho, Procurador-Geral da Corte de Cassação, magistrados, professores e advogados com mais de quinze anos de exercício profissional. Espanha - Presidente do Tribunal Supremo que também é o presidente do Conselho, advogados e outros juristas, todos de reconhecida competência e com mais de quinze anos de exercício em sua profissão. Portugal - presidido pelo Presidente do Supremo Tribunal de Justiça e composto por sete magistrados e sete cidadãos. França - Presidente da Repúb1ica, Ministro de Estado, cinco magistrados, cinco membros do Ministério Público, dez personalidades não pertencentes ao Parlamento ou a qualquer instância Judiciária ou administrativa. Argentina - Presidente da Corte Suprema de Justiça da Nação, quatro juízes, oito legisladores, quatro advogados e um representante do Executivo.

A ideia principal era consolidar um poder judiciário independente e autônomo.

Todas essas aspirações criaram na comunidade jurídica brasileira uma grande expectativa pela edição da Emenda Constitucional-EC que concretizasse o controle externo do Judiciário. Por outro lado, também era grande à resistência e a crítica a criação do controle, principalmente pela ala mais conservadora da magistratura.

Em 1992 foi apresentada a proposta, que após doze anos de tramitação foi aprovada, tendo sido promulgada na EC $\mathrm{n}^{\circ}$ 45/2004, conhecida como Reforma do Judiciário, disciplinando, em seu artigo 103-B, o Conselho Nacional de Justiça-CNJ.

Desde a instituição do $\mathrm{CNJ}$, é grande o embate provocado por sua atuação, principalmente na esfera administrativa, quando seus atos são constantemente questionados junto ao Supremo Tribunal Federal-STF.

No tocante ao aspecto administrativo o CNJ demonstra relevante desempenho prático, porém tem adotado algumas medidas de cunho decisório que extrapola seus limites administrativos exigindo, portanto, análise destes atos pelo STF. Nos últimos anos o que vemos são atos do CNJ, ora com poder de decisão judicial, ora com criação de normas de competência legislativa. 
Este trabalho, tem o objetivo de investigar como o STF vem se posicionando perante o desvirtuamento das decisões do $\mathrm{CNJ}$, eis que há uma distinção peculiar entre controle administrativo no poder judiciário e controle judicial. E ainda como está influenciando qualitativamente os demais processos que tramitam no STF sob o olhar do Supremo em números.

Os métodos para a captação e processamento de informações com o objetivo de resolver os problemas investigados consistiram em analisar a realidade de maneira crítica, à luz de concepções teóricas, com a finalidade de desenvolver a capacidade de observar, selecionar e organizar cientificamente os fatos da realidade.

\section{ASPECTOS HISTÓRICOS DO CNJ}

No Brasil, a tão falada Reforma do Judiciário, se iniciou em 1992 e finalmente chegou ao fim, após calorosos debates, no ano de 2004. Após doze anos de tramitação e várias emendas, o Projeto foi aprovado, tendo sido transformado na EC n 45/2004.

Inicialmente, foi Proposta a EC no 96/1992, de autoria do Deputado Hélio Bicudo. Na referida proposta, estava prevista a criação do CNJ como um órgão de controle externo do Judiciário e de composição híbrida, com participação de representantes de diversos setores da sociedade. A proposta sofreu forte pressão da massa contrária, capitaneada por componentes da magistratura e juristas como Carlos Mário da Silva Velloso e Luiz Flávio Gomes.

Em síntese, a crítica daqueles que são contrários ao controle externo do Poder Judiciário pode assim ser resumida: a) é mecanismo típico do sistema parlamentarista de governo, onde o Poder Judiciário não se constituiu em um poder político; b) não é compatível com o sistema presidencialista de governo, pois viola o princípio da separação dos Poderes; e c) a Constituição brasileira adota a doutrina dos freios e contrapesos, o que já seria suficiente para realizar o controle do Poder Judiciário. (Diário da Câmara dos Deputados, 1999, p. 1.064).

Historicamente, o CNJ não é um instituto inovador, antes de ser instituído no Brasil já repercutia na Europa na década de 50, tendo expandido sua força na América Latina em meados de $1980^{3}$. Na Europa as primeiras experiências nasceram na França, Itália, Portugal e Espanha. A ideia principal era consolidar um poder judiciário independente e autônomo. Isso

\footnotetext{
${ }^{3}$ Os Conselhos criados na América Latina surgiram em 1980. Segundo Ernani Carvalho (2013, p. 14), a pressão internacional e a percepção interna de poderes judiciários sem controles, lentos e pouco eficientes nas resoluções de conflitos cotidianos foram os combustíveis necessários para mover o pesado moinho da mudança institucional em prol da criação dos conselhos.
} 
porque o Poder Executivo no recém extinto período ditatorial reprimia e até mesmo controlava o Poder Judiciário.

Embora o primeiro Conselho tenha surgido na França ${ }^{4}$, país no qual o Judiciário tradicionalmente é subordinado aos demais Poderes, é o modelo italiano o mais influente na Europa Continental (GAROUPA; GINSBURG, 2008).

No Brasil diferente do que ocorreu na Europa, a criação do CNJ não procurava apenas manter a autonomia e independência já constitucionalmente assegurada, e sim garantir a unicidade do Poder Judiciário, através do controle das atividades administrativas e financeira, além da obediência aos deveres funcionais por parte dos magistrados, com o propósito de melhorar a atividade jurisdicional e amenizar aos poucos os erros e abusos que desonravam a sua história.

Várias foram as críticas a este padrão de conselho judicial, principalmente por parte dos magistrados, que diziam que se tratava de um controle externo do Poder Judiciário e era um “Tribunal para julgar juízes” (SAMPAIO, 2007, p. 240). Embora a reforma do judiciário introduzisse várias mudanças foi a criação do CNJ com a função de controlar administrativamente o Poder Judiciário que norteou diferentes sentimentos na seara jurídica.

Dallari (2002, p.146), sugeriu a implementação de um controle externo do judiciário como requisito da democracia, eliminando ações ou omissões daquele poder. Por sua vez, o STF, diversas vezes pronunciou-se pela impossibilidade de instituição do controle externo da magistratura em âmbito estadual, sob pena de afrontar a separação dos três poderes.

Cumpre ressaltar que a criação de um modelo de controle externo do Judiciário no Brasil sempre foi dificultada e vista com receio pela ala conservadora da magistratura. Mesmo após a promulgação da EC/45 de 2004, houve uma tentativa de barrar a criação do CNJ. Um dia após a promulgação da referida Emenda Constitucional, a Associação dos Magistrados do Brasil-AMB, propôs a Ação Direta de Inconstitucionalidade-ADI n. ${ }^{\circ}$ 3.367-1/DF, pretendendo a declaração de inconstitucionalidade da criação do CNJ, alegando, em síntese, violação ao pacto federativo, à separação de poderes e às prerrogativas de independência dos magistrados.

\footnotetext{
${ }^{4} \mathrm{Na}$ França, o Conselho tem por finalidade precípua atuar como um conselho de disciplina dos magistrados de carreira (art. 65 da Constituição francesa) Hipótese em que o Presidente da República e o Ministro da Justiça são substituídos pelo Primeiro Presidente da Corte de Cassação. O Conselho também possui as atribuições concernentes às nomeações, transferências e remoções de magistrados. (Diário da Câmara dos Deputados, 1999, p. 1.071).
} 
Em 13 de abril de 2005 o STF julgou, por maioria, improcedente a ADI 3.367-1/DF. Em seu voto, o Ministro Cezar Peluso asseverou que " $O$ Conselho não anula, reafirma o princípio federativo”. (PELUSO, Cezar. Voto na ação Direta de Inconstitucionalidade 3.3671. Pp 16)

\section{COMPETÊNCIAS ADMINISTRATIVAS DO CNJ}

A Constituição da República Federativa do Brasil de 1988-CR/88 diz que compete ao Conselho o controle da atuação administrativa e financeira do Poder Judiciário e do cumprimento dos deveres funcionais dos juízes ( $\$ 4^{\circ}$ do art.103-B). A natureza meramente administrativa do CNJ foi exarada na ADI-3367, onde o Supremo Tribunal Federal testificou: “(...) 2. Emenda Constitucional $n^{o}$ 45/2004. Poder Judiciário. Conselho Nacional de Justiça. Instituição e disciplina. Natureza meramente administrativa. Órgão interno de controle administrativo, financeiro e disciplinar da magistratura. Constitucionalidade reconhecida...." (ADI 3367, Relator(a): Min. CEZAR PELUSO, Tribunal Pleno, julgado em 13/04/2005, DJ 17-03-2006 PP-00004 EMENT VOL-02225-01 PP-00182 REPUBLICAÇÃO: DJ 22-09-2006 PP-00029)

O CNJ possui autoridade de controle administrativo interno do Poder Judiciário, ou seja, não confunde com a independência e autonomia da função judicante. Possui a essência de organizar o poder de modo a viabilizar suas atividades internas e externas.

Quando do julgamento da ADI 3.367, o STF decidiu que o CNJ tem controle administrativo, de índole interna, isto é, um controle em que não prejudica a autonomia e a independência do Poder Judiciário, mas sim, o organiza, tendo dever constitucional de "zelar pela autonomia" do Poder (art. 103-B, § 4, inc. I). "O Conselho não julga causa alguma, nem dispõe de nenhuma atribuição, de nenhuma competência, cujo exercício fosse capaz de interferir no desempenho da função típica do Judiciário, a jurisdicional”. (PELUSO, Cezar. Voto na ADI 3.367-1; p. 26-27).

Constitui-se, pois, o $\mathrm{CNJ}^{5}$, mais como órgão de coordenação e planejamento das atividades administrativas do Poder Judiciário, do que propriamente como órgão disciplinador, (MENDES. 2009, p. 5). No que tange a atividade externa, o CNJ poderá viabilizar aos tribunais um nivelamento mínimo dos serviços judiciais à disposição dos interlocutores do processo (partes, advogados, promotores, juízes e servidores) promovendo

\footnotetext{
${ }^{5}$ A atuação administrativa e financeira do Poder Judiciário está subdividida em cinco diretrizes: I planejamento estratégico e coordenação da política judiciária; II Modernização operacional e tecnológica; III ampliação do acesso à justiça, pacificação e responsabilidade social; IV garantia de respeito às liberdades públicas e execuções penais; fiscalização e controle do funcionamento das serventias judiciais e extrajudiciais (MENDES, 2009, p. 6).
} 
também, a uniformização administrativa dos tribunais com o apoio da tecnologia. Como exemplo, as ferramentas operacionais do BACENJUD, RENAJUD, INFOJUD e o sistema CNJ de processo eletrônico (Projudi), que são programas tecnológicos desempenhados em busca da justiça eficiente a serviço dos jurisdicionados.

Frise-se que a condição do CNJ como órgão de natureza administrativa o subordina ao império da lei e a vinculação aos princípios da Administração Pública, principalmente os constitucionais, uma vez que possui regime jurídico idêntico ao dos órgãos administrativos em geral. Isto ficou assente no julgamento da ADI 3367, quando o STF decidiu que o raio de alcance das medidas oriundas do CNJ, não têm o condão de vincular o STF enquanto órgão do Poder Judiciário, bem como os seus Ministros:

(...) 3. PODER JUDICIÁRIO. Caráter nacional. Regime orgânico unitário. Controle administrativo, financeiro e disciplinar. Órgão interno ou externo. Conselho de Justiça. Criação por Estado membro. Inadmissibilidade. Falta de competência constitucional. Os Estados membros carecem de competência constitucional para instituir, como órgão interno ou externo do Judiciário, conselho destinado ao controle da atividade administrativa, financeira ou disciplinar da respectiva Justiça. 4. PODER JUDICIÁRIO. Conselho Nacional de Justiça. Órgão de natureza exclusivamente administrativa. Atribuições de controle da atividade administrativa, financeira e disciplinar da magistratura. Competência relativa apenas aos órgãos e juízes situados, hierarquicamente, abaixo do Supremo Tribunal Federal. Preeminência deste, como órgão máximo do Poder Judiciário, sobre o Conselho, cujos atos e decisões estão sujeitos a seu controle jurisdicional. Inteligência dos art. 102, caput, inc. I, letra "r", e $\S 4^{\circ}$, da CF. O Conselho Nacional de Justiça não tem nenhuma competência sobre o Supremo Tribunal Federal e seus ministros, sendo esse o órgão máximo do Poder Judiciário nacional, a que aquele está sujeito. (ADI 3367, Relator(a): Min. CEZAR PELUSO, Tribunal Pleno, julgado em 13/04/2005, DJ 17-03-2006 PP-00004 EMENT VOL-02225-01 PP-00182 REPUBLICAÇÃO: DJ 22-092006 PP-00029)

A EC 45/2004, definiu a criação de dois órgãos com a atribuição de controle da atuação do Estado, o CNJ e o Conselho Nacional do Ministério Público. José dos Santos (2014. p. 953) exterioriza seu entendimento definindo o conceito de controle administrativo, "podemos denominar de controle da Administração Pública o conjunto de mecanismos jurídicos e administrativos por meio dos quais se exerce o poder de fiscalização e de revisão da atividade administrativa em qualquer das esferas de poder."

O controle é fundamental para legitimar a atuação do poder público, garantindo a adequação das condutas dos agentes públicos às necessidades da sociedade, de forma a permitir uma maior eficiência na execução das atividades públicas (CARVALHO, 2015. p. 
376). A razão da existência do controle administrativo ocorre por inúmeros motivos. O principal deles está na natureza humana. Embora a administração pública seja qualificada como um ente abstrato individualizado por pessoa jurídica de direito público ou mesmo pelos órgãos a ela vinculados, embora contemplados e regidos pelo princípio da legalidade, a execução dos seus atos emana da ação humana, melhor dizendo, de seus agentes.

Como é sabido o homem pode desvirtuar os interesses da Administração Pública acarretando seu ato na ilegalidade ou abusividade e, para sanar esses vícios, imprescindível um órgão especial para combater comportamentos de índole evasiva ao interesse público. Portanto, mencionar controle administrativo é discorrer a aptidão que os órgãos de administração pública exercem sobre sua própria atividade, visando mantê-la dentro da lei.

O controle administrativo pode ser encontrado nos três poderes do Estado. ${ }^{6}$ Entretanto, há uma sutil diferença entre Controle Judiciário e o Controle Administrativo no poder judiciário. O primeiro, Controle judiciário explica Matheus Carvalho:

O controle judicial é realizado pelo Poder Público, mediante provocação de qualquer interessado que esteja sofrendo lesão ou ameaça o de lesão em virtude de conduta ou omissão administrativa que o atinja direta ou indiretamente. Nestes casos, o controle será exercido somente no que tange aos aspectos de legalidade dos atos administrativos, ainda que se trate de ato praticado no exercício da competência discricionária, haja vista a impossibilidade de substituição do mérito administrativo pela opção do julgador( 2015. p. 377).

A atuação judicial irá incidir, exclusivamente, na legalidade do ato administrativo e para realizar o controle exige a provocação do interessado que esteja sofrendo lesão ou ameaça decorrente do ato que provém da administração pública e, para isso, mediante ação judicial (mandado de segurança; habeas data; mandado de injunção; ação popular; ação civil pública; ação de improbidade).

Já o segundo, Controle Administrativo no poder judiciário, são os poderes de autotutela inerente à sua administração:

\footnotetext{
${ }^{6}$ José do Santo Carvalho Filho (2014p. 955), discorre as espécies de controle quanto a natureza do poder controlador: Controle legislativo - é aquele executado através do Poder Legislativo sobre os atos da Administração Pública. Exemplo, o controle exercido pelos Tribunais de Contas, órgãos de controle financeiro que integram o Legislativo das diversas esferas da federação; Controle judicial - é o levado a efeito pelo Poder Judiciário. Cabe a este Poder a decisão sobre a legalidade, ou não, de atos da Administração em geral, principalmente em casos de conflitos de interesses. Exemplo, ações judiciais na quais se discuta sobre a legalidade de atos administrativos; Controle administrativo - é o que se origina da própria Administração Pública. Significa aquele poder que têm os órgãos que a compões, de fiscalizarem e reverem seus próprios atos, controle, aliás, normalmente denominado de autotutela. Exemplo, revogação de um ato administrativo.
} 
O controle administrativo decorre do poder de autotutela conferido à Administração Pública que deve efetivar a fiscalização e revisão dos seus atos, mediante provocação ou de ofício, com a finalidade de verificar os aspectos de ilegalidade que maculem o ato controlado, situações que ensejam a anulação do ato - e também ausência de interesse público na manutenção da conduta no ordenamento jurídico, podendo justificar sua revogação (2015. p. 378).

Excepcionalmente, o poder judiciário exercerá atipicamente o controle administrativo $^{7}$. O $\S 4^{\circ}$ do art.103-B da CR/88, traz a competência material e normativa do CNJ. O CNJ exerce competência normativa interna, como por exemplo, elaboração de seu Regimento Interno, bem como competência normativa externa, por exemplo, quando edita Resoluções e recomendações. A competência normativa também é exercitada quando há a estipulação de normas de conduta a serem seguidas. O exercício da competência material se dá quando há a prática de atos que não produzem efeitos jurídicos, como por exemplo, a elaboração de relatórios.

Analisando os limites das suas diretrizes o objetivo do CNJ nos leva a uma interpretação, todas as atribuições são de cunho administrativo, podendo fracionar-se em medidas informativas, correicionais, disciplinares, sancionatórias, ouvidoria etc.

Nesses vieses, desde que em função administrativa, o controle administrativo pelo CNJ poderá revogar, anular ou modificar seus próprios atos e, até mesmo punir seus agentes com as penalidades estatutárias, previstas na Lei Orgânica da Magistratura Nacional (LC n 35/1979).

O curso inicial do processo se dará por várias vias, ${ }^{8}$ até mesmo de ofício. São várias as espécies processuais, conforme a finalidade a que se destina. Processo Administrativo Disciplinar-PAD, por exemplo, insculpido nos artigos 73 a 77 do Regimento Interno do CNJ-

\footnotetext{
${ }^{7}$ José Adércio Leite Sampaio elucida a posição administrativa do CNJ localizado no âmbito do Poder Judiciário: "O Conselho Nacional de Justiça é órgão administrativo-constitucional do Poder Judiciário da República Federativa do Brasil com status semiautônomo ou de autonomia relativa. A estatura constitucional decorre da sua presença no texto da Constituição. A natureza administrativa é dada pelo rol de atribuições previstas no artigo constitucional 103-B, $\S 4^{\circ}$, que escapam ao enquadramento, obviamente, legislativo, uma vez que não pode inovar a ordem jurídica como autor de ato normativo, geral e abstrato, e, por submeter-se ao controle judicial, ainda que pelo STF, escapa da feição jurisdicional”. (2007. p. 263) g.n.

${ }^{8} \mathrm{O}$ RI/CNJ prevê no Capítulo I do Título II - Art. 42. Os requerimentos iniciais, as reclamações disciplinares, os processos instaurados de ofício e os processos recebidos de outros órgãos. Por sua vez, o Art. 43, discrimina as seguintes classes processuais: I - Inspeção; II - Correição; III - Sindicância; IV - Reclamação Disciplinar; V Processo Administrativo Disciplinar; VI - Representação por Excesso de Prazo; VII - Avocação; VIII - Revisão Disciplinar; IX - Consulta; X - Procedimento de Controle Administrativo.
} 
RI/CNJ é destinado a apurar responsabilidades de magistrados por infração disciplinar, refletindo em punição administrativa. ${ }^{9}$

Embora o CNJ prime pela transparência, o art. 17 do RI/CNJ faculta aos conselheiros o direito de registrar em ata o sentido de seus votos, juntando, se entenderem convenientes, seus votos. Esta medida facultativa dificulta a transcrição dos votos e sua respectiva fundamentação aos processos instaurados na cúpula do $\mathrm{CNJ}$, sobretudo, quando magistrados são investigados.

Recentemente, por exemplo, a "Agência CNJ de notícia"10 veiculou matéria a respeito da instauração do PAD $n^{\circ}$ 0006316-73.2011.2.00.0000 contra o desembargador do Tribunal de Justiça do Estado do Rio de Janeiro (TJRJ) L. Z. Suspeita-se que o magistrado favoreceu a incorporadora Cyrela em processo judicial no qual se discutia a propriedade de um terreno localizado na Barra da Tijuca, no Rio de Janeiro/RJ.

Outro fato envolvendo magistrado ocorreu no PAD 0004931-56.2012.2.00.0000, em sede de liminar e sem ouvir a parte contrária, o juiz liberou uma quantia superior a $\mathrm{R} \$ 1,5$ milhão de reais. No voto do Relator Conselheiro Walter Nunes, considera dolosa a atividade do magistrado que liberou elevada quantia sob o fundamento de independência funcional:

Como se nota, conquanto necessário e represente importante avanço na processualística moderna, o instituto da tutela antecipada, caso dolosamente deturpado, pode transformar-se em perigoso instrumento para o exercício indevido da função jurisdicional, notadamente para a prática de irregularidades.

Infelizmente, sem embargo da cautela legislativa, não têm sido raros os casos analisados por este Egrégio Conselho em que magistrados, utilizando

9 a) Sindicância (RI/CNJ, arts. 60 a 66): procedimento investigativo sumário levado a efeito pela Corregedoria Nacional de Justiça, que pode resultar em processo administrativo disciplinar.

b) Reclamação Disciplinar (RI/CNJ, arts. 67 a 72): dirigida em requerimento assinado ao Corregedor Nacional de Justiça, pode resultar em uma sindicância, para investigação dos fatos, ou em um processo administrativo disciplinar, caso as provas de infração sejam suficientes.

c) Processo Administrativo Disciplinar (RI/CNJ, arts. 73 a 77): instrumento destinado a apurar responsabilidades de magistrados por infração disciplinar praticada no exercício de suas atribuições, podendo resultar em sua punição administrativa definitiva.

d) Revisão Disciplinar (RI/CNJ, arts. 82 a 88): processos disciplinares de juízes e membros de Tribunais julgados há menos de um ano que poderão ser revistos. Julgado procedente o pedido de revisão, o Plenário do CNJ poderá determinar a instauração de processo administrativo disciplinar, alterar a classificação da infração, absolver ou condenar o juiz ou membro de Tribunal, modificar a pena ou anular o processo.

${ }^{10} \mathrm{O}$ caso teve início com uma reclamação ao CNJ (0002979-13.2010.2.00.0000) feita por Vanildo Pereira da Silva. Ele é sócio da empresa Elmway, que disputa a propriedade com a incorporadora Cyrela, responsável pela construção de um condomínio de luxo no local. No primeiro julgamento em outubro, a corregedora defendeu a abertura do processo contra L.Z. Segundo as denúncias, o magistrado - na época, presidente do Tribunal de Justiça do Rio - teria fornecido informações, favorecendo assim a incorporadora, quando da análise do caso pela corte fluminense. Em seu voto, a ministra Eliana Calmon destacou os vínculos entre a Cyrela e L.Z. O escritório de advocacia da família do magistrado, por exemplo, é patrocinadora de várias causas da empresa. (SOUZA, 2016). 
como escudo a independência funcional e o poder de conceder tutela antecipada, têm, mediante decisões no mínimo teratológicas, determinado a liberação de altas quantias, com sobradas evidências de atuação dolosa, a partir mesmo da circunstância de o processo chegar a sua pessoa, ainda que não seja o caso, por meio de distribuição por dependência. ${ }^{11}$

Nos últimos anos, outro fato que marcou o CNJ foi a punição a uma magistrada do Pará, que foi aposentada compulsoriamente por ter mantido presa por cerca de um mês uma adolescente com outros 26 homens. Nesse caso, assentou o relator:

Admitir a ausência de responsabilidade da magistrada neste evento seria de forma transversa, reconhecer a incompetência do Poder Judiciário em proteger os direitos e garantias fundamentais de qualquer cidadão, ainda que em situação de encarceramento. ${ }^{12}$

Além das decisões administrativas o CNJ aprovou diversas resoluções. Dentre estas, Pedro Lenza (2009. p. 576) destaca duas: "Destacamos duas importantes Resoluções, a de n. 7, que proíbe o nepotismo, e a de n. 11, que disciplina o conceito de atividade jurídica de 3 anos como requisito para o ingresso na Magistratura."

Observa-se que o CNJ contribui indiscutivelmente para o fortalecimento do Poder Judiciário. Inúmeras ponderações foram realizadas, inclusive, sua legitimidade administrativa incorporada no Poder Judiciário. No entanto, a incessante luta para promover a justiça dentro do próprio poder vêm tomando novas direções para o órgão, avocando para si matérias de natureza jurisdicional e legislativa, proporcionando verdadeiro embate judicial com o STF.

\section{A ATUAÇÃO DOS CONSELHEIROS}

Na pesquisa realizada na dissertação de mestrado no ano de 2015, Ivan Franco, analisa a postura dos conselheiros conforme sua origem de atuação profissional e a relação com sua votação no plenário do CNJ, para isso, o autor dividiu dois grupos: Conselheiros juízes e Conselheiros não juízes.

Proporcionalmente $40 \%$ dos conselheiros do CNJ são compostas por integrantes desvinculados à magistratura (advogado, representantes do ministério público e juristas indicados pelo Congresso Nacional). Os Conselheiros juízes correspondem 60\% e ocupam os

\footnotetext{
${ }^{11}$ Voto do Relator Conselheiro Walter Nunes, PAD 0005993-05.2010.2.00.0000, j. 122ª Sessão Ordinária, p. 56).

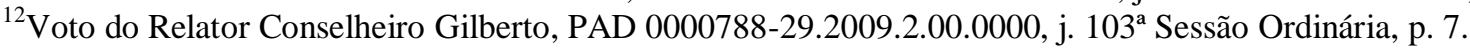


principais cargos do CNJ, Presidência (ocupado pelo Ministro do STF) e a Corregedoria (ocupado pelo Ministro do STJ).

Os dois primeiros anos de adaptações do CNJ não possuem números específicos no tocante às punições dos magistrados, mas com o surgimento da Resolução 30/2007 o CNJ regulamenta os procedimentos administrativos disciplinares de modo a tornar eficiente o controle disciplinar.

Nas carreiras relacionadas ao campo jurídico existe uma competência interna de supremo interesse de representatividade profissional. Cada área específica do direito é particularmente parcial e tendencioso no tocante ao ego profissional, por exemplo, potenciais conflitos entre advogados, promotores e juízes. Tanto que inúmeras as representações das entidades de classes (Associação dos Magistrados Brasileiros - AMB; Associação dos Juízes Federais do Brasil - AJUFE; Associação dos Juízes Federais do Estado de São Paulo AJUFESP; Associação Nacional dos Magistrados da Justiça do Trabalho - ANAMATRA).

O CNJ é representado por uma pluralidade de carreiras específicas de modo que membros de distintas carreiras integram o mesmo colegiado para produzir normas regulamentadoras e o poder de decisão sobre a possibilidade de punir ou não o magistrado mediante as variadas sanções (advertência; censura; disponibilidade; aposentadoria compulsória para os magistrados vitalícios e demissão para os juízes ainda não vitalícios). Logo, o conflito de votos no colegiado é previsível.

Para isso, verifica-se que desde a primeira Sessão Plenária do CNJ, realizada em 17 de Junho de 2005, até a última Sessão do ano de 2013, totalizam 181 Sessões Ordinárias e 20 Sessões Extraordinárias. No lastro de oito anos, várias as características decisórias no Conselho e sua composição, por exemplo, nesse período vem predominando a indicação dos juízes estaduais do Tribunal de Justiça do Estado de São Paulo e Rio de Janeiro.

Segundo apurado, nos dois primeiros anos os números divulgados pela Corregedoria dão conta do impacto da atuação do CNJ, 26 juízes se aposentaram para evitar a abertura de processo administrativo disciplinar. No biênio 2004-2005, resultaram 82 sanções, no biênio 2005-2007 foram 140. Dados da Corregedoria Nacional de Justiça versa que nesse período a pena mais rigorosa aplicada aos magistrados, aposentadoria compulsória, elevou de 6 para 20.

No período compreendido entre 2005 a 2013, foram recebidos 48.910 processos, razão que 34.211 foram para a Corregedoria e 14.676 distribuídos para os demais conselheiros, ou seja, $69,9 \%$ dos processos de todo o $\mathrm{CNJ}$ foram concentrados ao poderio da 
Corregedoria Nacional de Justiça. Isso leva a crer o poder do corregedor de nortear as decisões na dinâmica do CNJ.

Outra curiosidade dos 399 casos analisados na pesquisa, 305 foram decididos por unanimidade e 94 por maioria. Portanto, $76 \%$ dos casos são decididos por unanimidade de votos. Ressalta-se que esses números correspondem aos casos passíveis de gerarem sanções disciplinares definitivas, as quais poderão ser decididas pelo plenário do CNJ. Desse modo, a análise processual delimita 399 casos em face de 48.910 processo recebidos pelo CNJ.

Destaca mencionar que na gestão da Corregedora Eliana Calmon (biênio 2010-2012) o encaminhamento dos processos para a Corregedoria aumentou sobremodo o percentual para $75,80 \%$.

Dos 399 casos analisados até o ano de 2013, são 56 sindicâncias, sendo 16 (29\%) delas extintas/arquivadas e 40 casos (71\%) refletindo na abertura de processo administrativo disciplinar (PAD) podendo levar a punição definitiva do magistrado. Esse último índice é um dado de extrema alerta para a postura do $\mathrm{CNJ}$, pois dos 40 casos levados ao PAD 24 há medida liminar aplicada demonstrando uma tendência do Conselho em afastar o magistrado antes do processamento do PAD.

Numa base de 106 votos proferidos, sendo 62 por Conselheiros juízes e 44 Conselheiros não juízes apurou-se o índice de divergência pró-magistrado (contrária a abertura de um PAD) de grupo de sindicâncias correspondendo 24,2\% de Conselheiros juízes e 4,6\% de Conselheiros não juízes. Dentre os votos divergentes a cadeira do Conselho ocupada por Desembargador do TRF, tem um índice de $75 \%$ maior do que dos conselheiros juízes enquanto grupo, o que demonstra uma postura favorável ao magistrado sob julgamento. Outro destaque está para os índices dos conselheiros da Justiça do Trabalho, pois tanto a justiça federal quanto a trabalhista reina uma concepção corporativista devido o vínculo de seus membros com associações de classe da magistratura.

Insta destacar a função essencial do Corregedor Nacional de Justiça para os trabalhos do CNJ. O cargo ocupado por um Ministro do STJ tem atribuições aptas a influenciar os caminhos decisórios do processo administrativo, pois além de conduzir as investigações é responsável por relatar os processos e proferir o primeiro voto. Segundo dados do CNJ o Corregedor não foi derrotado em nenhum dos julgamentos realizados para apurar o processo de sindicância. 
Nesse mesmo período (2005-2013) o pesquisador $^{13}$ apurou o resultado dos votos no âmbito de Processos Administrativos Disciplinares (PAD) ${ }^{14}$. O CNJ é o responsável pelo julgamento definitivo de magistrados podendo a decisão ser revisada apenas pelo STF.

Computam-se nesse interstício 72 casos de PAD julgados pelo CNJ. Os dispositivos decisórios possíveis no $\mathrm{PAD}$ são de improcedência quando o magistrado não é considerado culpado, portanto, decisões pró-magistrado. Por sua vez, há decisão de procedência quando o magistrado é considerado culpado e recebe uma sanção administrativa, logo, decisões contramagistrado.

Dos 72 casos são 18 (25\%) julgados improcedentes, 38 casos (53\%) resultaram em aposentadoria compulsória, 8 casos $(11 \%)$ censura, 5 casos $(7 \%)$ em disponibilidade, 2 casos (3\%) em remoção compulsória e 1 caso (1\%) em advertência. Nessa vertente, 47 decisões foram julgadas por unanimidade e 25 decisões votadas em maioria pelos Conselheiros.

Na margem de 224 votos proferidos pró-magistrado, são 135 decididos Conselheiros juízes, destes apenas 28 votos houve divergência (20,7\%). Pelos Conselheiros não-juízes são 89 votos e apenas 3 divergência desse total $(3,4 \%)$.

Os resultados obtidos nos votos proferidos contra-magistrados correspondem 157 casos, desses foram 93 votos proferidos por Conselheiros juízes e 16 divergentes (17,2\%). Enquanto os Conselheiros não-juízes produziram 64 votos, sendo 34 divergentes $(53,1 \%)$.

Os percentuais analisados demonstram com nitidez a distinção de posicionamentos (por profissão) dos Conselheiros do CNJ. Nos casos decididos sem unanimidade, é notável maior pretensão de defesa dos votos favoráveis aos magistrados sob julgamento pelos Conselheiros juízes e maior a tendência de punição por Conselheiros não juízes.

Mantendo a mesma postura em relação às demais modalidades de procedimentos administrativos os juízes e desembargadores do TRF consolidam elevado índice de divergência pró-magistrado, aspecto favorável ao magistrado sob judice.

Diferentemente do que ocorreu nas outras classes processuais o Corregedor Nacional de Justiça ao conduzir os Processos Administrativos Disciplinares (PAD) não mais relata

\footnotetext{
${ }^{13} \mathrm{O}$ autor Ivan Franco cita o trabalho de Roberto Fragale com o intuito de complementar os dados da dissertação de mestrado. Pois, Fragale em: "Conselho Nacional de Justiça: Desenho Institucional, Construção de Agenda e Processo Decisório" com a finalidade de entender a composição do CNJ, utilizou como estratégia estudar conjuntamente os membros e os órgãos que os indicam.

${ }^{14}$ Processo Administrativo Disciplinar tem a peculiaridade de verificar os indícios manifestamente reveladores de comportamentos equívocos e suspeitos de juiz. O CNJ é o responsável pelo julgamento definitivo de magistrados podendo a decisão ser revisada apenas pelo STF.
} 
todos os casos, embora aqueles por ele relatados foram acompanhados de forma unânime pelos demais Conselheiros.

Os votos de divergência do Corregedor Nacional de Justiça contra-magistrado é imensamente maior ao voto pró-magistrado, proporção de $45,5 \%$ para $7,1 \%$. A característica peculiar do Corregedor dentro do CNJ com a atribuição de conduzir, relatar e votar, distância naturalmente da função de conselheiro juiz. No mesmo raciocínio está na postura do Presidente do CNJ, cuja decisão quando divergente representa $30 \%$ contra-magistrado e $7,1 \%$ pró-magistrado.

A justificativa para o posicionamento dos votos divergentes (contra-magistrado e pró-magistrado) dos Ministros do STF e STJ centram-se na origem profissional das respectivas carreiras, decorrente de outras não ligadas à magistratura. Os Ministros do STF que presidiram o CNJ com exceção do Min. Cezar Peluzo (2010-2012), nunca atuaram na magistratura previamente, veja: Nelson Jobim (biênio 2005-2006) oriundo da advocacia, Ellen Gracie (2006-2008) começou a carreira como Procuradora da República, Gilmar Mendes (2008-2010) antes ocupou o cargo de Advogado Geral da União e Procurador da República, Ayres Brito (2012) teve atuação na advocacia e o Min. Joaquim Barbosa (20122014) fez carreira como Procurador da República.

Da mesma forma os Ministros do STJ que ocupam o cargo de Corregedor Nacional de Justiça apenas a Min. Eliana Calmon (biênio 2010-2012) é juíza de carreira, os demais Antônio de Pádua Ribeiro (2005-2007), Cesar Asfor Rocha (2007-2008), Gilson Dipp (20082010), Francisco Falcão (2012-2014) iniciaram suas carreiras na advocacia.

Os grupos dos Conselheiros não juízes com os membros do ministério público e advogados aparecem com grande destaque nos votos divergentes contra-magistrados. O integrante do Ministério Público da União apresentou 36,4\% deste índice e o do Ministério Publico Estadual $81,8 \%$. Os advogados demonstram também larga disparidade na votação contra-magistrado $54,5 \%$.

Nesse sentido, coincidência ou não, fato é que os números e não seus fundamentos demonstram que os votos dos Conselheiros não juízes e dos Conselheiros juízes (Ministros do STF e STJ), mas que têm origem profissional diversas da magistratura possuem uma tendência de julgar contra-magistrados nos processos administrativos em trâmite no CNJ, ou seja, decisões propensas à punição que acarretam às sanções expressivas como a aposentadoria compulsória. 


\section{LIMITES DO CONTROLE ADMINISTRATIVO DO CNJ}

Os atos emanados do CNJ reverbera a mudança de paradigmas no cotidiano dos tribunais. Aliás, será que o CNJ conseguiu limitar o campo de atuação na ideia preliminar de aprimoramento de gestão, uniformização administrativa, efetividade processual e combate aos atos abusivos dos atores do poder judiciário? Ou será que no decorrer da instituição como órgão administrativo de controle interno do poder judiciário o $\mathrm{CNJ}$ vai além do relevante papel administrativo ao ponto de usurpar as funções típicas dos Poderes, legislativo e Judiciário? Ainda, a formação de origem dos Conselheiros não juízes do CNJ influência desfavoravelmente a decisão dos magistrados sub judice?

Sabemos que o novo proporciona curiosidade, indagações e receios, pois algo acaba mudando. Não foi e muito menos está próximo de encerrar os embates vivenciados no STF desde a criação do $\mathrm{CNJ}^{15}$.

Quando do julgamento da ADI 3.367 (Rel Min. Cezar Peluzo, j. 13.04.2005, DJ de 22.09.2006), conclui-se que ao $\mathrm{CNJ}$ : a) não é permitido rever as decisões dos magistrados no âmbito do processo, pois limitado ao âmbito administrativo; b) está hierarquicamente subordinado ao STF, logo suas decisões poderão ser reformadas pela Suprema Corte; c) a competência está adstrita ao Poder Judiciário, não podendo interferir administrativamente nos poderes Executivo e Legislativo, lembre-se que faz o controle administrativo do poder judiciário; d) possui natureza administrativa interna.

No entanto, nos últimos anos a realidade pertinente aos atos do CNJ não coadunam com os limites estampados na decisão do STF, tornando inviáveis as premissas da efetividade administrativa sustenta pelo CNJ. Essa observação é extraída do projeto "I Relatório Supremo

\footnotetext{
15 Outro aspecto importante a ser ressaltado é o relacionado ao Conselho Nacional de Justiça (CNJ). De acordo com a Constituição, compete ao STF julgar os mandados de segurança impetrados contra decisões proferidas pelo CNJ (art. 102, I, r). Em razão disso e da atuação bastante expressiva que o CNJ vem apresentando desde sua instalação em 2005, é razoável que se investigue se esta nova via estaria representando sobrecarga ao STF.

Conforme demonstra o Gráfico 15 abaixo, o impacto dos processos contra decisões do CNJ mostra-se insignificante, somando 458 processos entre 2005 e 2009. Diante do total de processos do Supremo Ordinário neste mesmo período, 32.113, não chegam a representar $1,5 \%$. Se comparados com o total das 3 personas do Supremo, que somam 420.975 entre 2005 e 2009, os casos provenientes do CNJ representam apenas 0,1\% dos processos. Importante notar que em nosso banco não constam os recentes mandados de segurança impetrados por responsáveis por serventias extrajudiciais atacando a determinação de afastamento em massa dos não concursados (cerca de 5 mil pessoas afetadas) pela Corregedoria Nacional de Justiça. Mas mesmo que considerássemos que todos os afastados impetrassem mandados de segurança junto ao STF, são todos relacionados a uma única decisão do $\mathrm{CNJ}$, de forma que poderão ser tratados conjuntamente. Bastará decidir um para decidir todos (FALCÃO; CERDEIRA; ARGUELHES, 2011, p. 53).
} 
Em Números: O múltiplo supremo"16 onde pesquisa realizada pelo $\mathrm{STF}^{17}$ revela que entre 2005 e 2009 somaram 458 processos em trâmite no STF com a finalidade de reformar/cassar decisões do CNJ que ultrapassam os limites da legalidade e da razoabilidade. Destaca-se que não está mais em pauta a existência do $\mathrm{CNJ}$, mas os atos executados por este órgão.

Analisando os dados do I Relatório Supremo em Números, constata que os mandados de segurança impetrados contra decisões proferidas pelo CNJ não vem representando quantitativamente sobrecarga para o STF se comparado aos números de demandas processuais de natureza distinta. Além disso, os dados levantados não computam os mandados de segurança impetrados por serventias extrajudiciais, afetando mais de 5 mil pessoas, porquanto, trabalhados conjuntamente, uma decisão produzirá efeito a todos os impetrantes.

A propósito, se os números analisados numa ótica quantitativa não produzem relevância para os trabalhos do STF, a nosso ver, sob uma vertente qualitativa representa significativo valor. Pois, as decisões da Corte Constitucional, oriundos dos conflitos que possuem como parte o $\mathrm{CNJ}$, repercutem em toda sistematização administrativa do poder judiciário, ou seja, vários servidores, tribunais e magistrados, inclusive, a sociedade.

Diante dessa expressiva extrapolação de limites, percebe-se que várias resoluções editadas pelo CNJ desviaram da feição administrativa, assim ocorreu com a edição das Resoluções no 115/10 e 123/10, oportunidade que o governo do Estado do Pará ajuizou a ADI 4465, contra o $\S 1^{\circ}$ do art. 22 da Resolução 115 de 2010, do CNJ. neste caso o Relator Min. Marco Aurélio deferiu a medida cautelar, para suspender a eficácia da norma questionada, cosignando que o CNJ excedera os limites da atribuição administrativa, ressaltando ainda, que o órgão CNJ não possui poder normativo. Enfim, arrematou observando que o ato administrativo configura usurpação de função ao aferir o campo de execução de débito da Fazenda Pública.

Noutro caso, o CNJ extrapolou seu limite de atuação ao suspender a decisão do Poder Judiciário do TJMA em sua função típica, no entanto o plenário do STF a modificou, mantendo as liminares e suspendendo, naquela oportunidade, duas decisões do CNJ,

\footnotetext{
${ }^{16}$ A pesquisa desenvolvida por Joaquim Falcão, Pablo de Camargo Cerdeira e Diego Werneck intitulado "I Relatório Supremo Em Números: O múltiplo supremo" possui o objetivo de realizar análises quantitativas, de massa, sobre o comportamento do principal órgão de cúpula do Poder Judiciário: o STF. [...]. O objetivo do Supremo em Números, em oposição ao modelo de análise qualitativa mais difundido, é fundamentar quantitativa e estatisticamente discussões sobre a natureza, a função e o impacto da atuação do STF na democracia brasileira (2011, p. 11).

${ }^{17}$ Comparando os dados do total de processos do Supremo Ordinário neste mesmo período, 32.113, não chegam a representar 1,5\% (FALCÃO; CERDEIRA; ARGUELHES, 2011, p. 53).
} 
tornando-as sem efeito. Trata-se da manutenção das liminares do TJMA que conferiram titularidade ao Cartório do $2^{\circ}$ Ofício Extrajudicial de Barra da Corda-MA a Iolanda Nepomuceno e a titularidade do Cartório de Balsas-MA à Maria do Socorro. Neste caso, ao acompanhar o voto do relator, o ministro Gilmar Mendes lembrou que, em ambos os processos, já foram interpostos RESPs no STJ e REs junto ao STF. Segundo ele, "está inequivocamente comprovada a impropriedade da decisão do CNJ, pois ele não pode interferir em decisões judiciais, embora estas possam refletir-se no campo administrativo".

Não obstante, além de sentir-se confortável para usurpar a função legislativa o CNJ amplia arbitrariamente seus poderes avocando as atribuições de caráter decisório específico do Poder Judiciário. Em 2006, por exemplo, o STF já havia posicionado no sentido de reconhecer as limitações do controle de atuação administrativa do CNJ, veja: "CNJ competência restrita ao controle de atuação administrativa e financeira dos órgãos do Poder Judiciário a ele sujeitos.” MS 25.879-AgR, Rel. Min. Sepúlveda Pertence, j. 23/08/2003, DJ de 08/09/2006.

Estreitando seus rigorismos, os Ministros da Suprema Corte, foram além, decidindo que o CNJ não tem poderes para punir os magistrados, sem antes, exaurir as possibilidades de investigação pelos tribunais a eles vinculados.

Além desses limites, nota-se a postura do STF frente a cúpula de conselheiros do $\mathrm{CNJ}$, sendo fundamental para compreender o distanciamento do (des)controle administrativo judicial decorrente dos atos do CNJ. Ora, ao verificar atos do CNJ cassados ou reformados pelo STF, transmitir-se-á uma sensação de insegurança jurídica, não pelo Poder Judiciário propriamente dito, e sim, pela administração deste poder em relação aos seus administrados.

As Adins contra os atos do CNJ têm sido bastante frequentadas na cúpula do STF objetivando conter as limitações da competência constitucional do CNJ, fora os mandados de segurança em que os magistrados e demais servidores requerem anulação de decisões do Conselho.

Joaquim Falcão critica a postura do STF, que tem sido muito cauteloso ao apreciar as Adins ajuizadas contra o $\mathrm{CNJ}^{18}$. Como observado acima, são ações cujas eventuais decisões

\footnotetext{
${ }^{18} \mathrm{O}$ que mais assusta a postura omissa do STF está no fato de não decidir definitivamente o mérito das 32 Adins. Joaquim Falcão aduz que: $O$ Supremo na verdade está entre a cruz e a espada. De um lado, a permanente pressão dos desembargadores e ministros insatisfeitos e que têm acesso institucional privilegiado, quase diário, aos ministros do Supremo, e que defendem Adins e mandados de segurança largamente ligados a interesses corporativos. De outro, a difícil decisão de restringir o formato institucional que o Congresso Nacional deu ao CNJ. Há que bem avaliar a possibilidade de uma reação do Congresso, da opinião pública e da mídia (9). O Congresso pode responder a interpretações limitadoras do poder do CNJ com novas emendas ao texto
} 
terão expressivo e imediato impacto sobre as diretrizes traçadas pelo CNJ. Pois a figura do presidente do CNJ sendo a mesma ocupada pela presidência do STF soa no mínimo a necessidade de decidir os entraves jurídicos sem retirar o empenho legislativo decorrente do Congresso Nacional ao aprovar a EC 45/2004.

Afinal, o descompasso entre CNJ e STF precisa ser revisto, destaca-se, pela primeira instituição, pois a segunda já o faz, cassando os atos ilegais ou abusivos do órgão administrativo. A propósito, sobrepor seus limites, burlar as regras do jogo ou tentar promover a concepção do justo sem qualquer respeito às modalidades técnicas atribuídas a cada órgão, sem dúvida, alimentando está a indolência da injustiça.

O choque de paradigmas encaminhados ao STF põe em conflito a independência da decisão do juiz e o controle administrativo. Nesse embate, a imparcialidade do magistrado prevalece em cumprimento ao princípio da livre convicção, medida adotada expressamente no inciso, I, do Art. 35 da lei orgânica da magistratura LOMAN- São deveres do magistrado: Cumprir e fazer cumprir, com independência, serenidade e exatidão, as disposições legais e os atos de ofício. Oportuno as palavras de Falcão, Arguelhes e Cerdeira:

\footnotetext{
Neste sentido, observar como o STF tem reagido a essas estratégias é fundamental para entender o processo de construção da identidade e das competências do CNJ. Afinal, ao rever uma medida tomada pelo CNJ, usando da competência prevista no artigo 102, I, r da Constituição, o STF demarca fronteiras. Fecha alguns caminhos, abre outros. Seja por meio de pontuais, mas impactantes leading cases, seja por intermédio de uma grande gama de decisões repetidas, a atividade decisória do STF (re)constrói o CNJ. Até que essa identidade se estabilize, a judicialização permanente de demandas relativas à atuação do $\mathrm{CNJ}$ é nada menos que um novo round de desenho institucional (2012, p. 03).
}

O juiz deve, em todos os casos, interpretar a lei precisamente pelo que conduza à conclusão mais justa para o problema colocado perante sua jurisdição, porque o único método interpretativo válido e correto é o que vem da lógica do humano, do razoável (DINAMARCO. 2009, p. 18).

Aos poucos os riscos institucionais podem simbolizar insegurança jurídica para os jurisdicionados, posto que afeta diretamente os números do múltiplo supremo, procrastinando

constitucional, por exemplo (10). Seria um processo, se não de retaliação entre os poderes, pelo menos de renovação de uma tensão que vinha sendo democraticamente administrada. Afinal, eventual decisão unilateral do Supremo de retirar competências do CNJ implicaria o rompimento do pacto político-institucional que permitiu a aprovação da Emenda 45 (11). (2012, p. 07) 
a solução das demandas ordinárias e extraordinárias para agora revisar o conflito interno dos órgãos subordinados e seus atores.

Essas medidas processuais que abarrotam o STF acabam por sua vez distanciando da razoável apreciação que se esperam da corte máxima do país. A tardia decisão protraída no tempo já não é aquela que se espera das partes, a visão da justiça queda-se ofuscada e a razão da equidade dispersa sobre máquina judiciária.

Tempo e segurança somados são a dimensão fundamental da vida humana, e o bem jurídico apreciado no processo interfere no estado de espírito das partes que o reivindicam. Por isso, a prestação de uma tutela jurisdicional intempestiva fomenta desprestígio para o poder judiciário.

Desse jeito, exprime a dúvida se o CNJ continuará a exorbitar competências que não são suas, usurpando atividades típicas de outros Poderes ou se irá se preservar a finalidade de sua criação, exercendo o controle exclusivamente administrativo do Poder Judiciário.

\section{CONSIDERAÇÕES FINAIS}

A reforma do judiciário ao criar o $\mathrm{CNJ}$, vai muito além da busca da necessidade de agilização da prestação jurisdicional. O controle administrativo interno atribuído ao CNJ precisa ser bem compreendido pelos seus Conselheiros, de modo que o órgão se limite às atividades administrativas que motivaram sua criação.

O CNJ é importante para a uniformização administrativa dos tribunais de todas as unidades da federação.

Os dados do CNJ em números revelam que no período de 2005 até 2013 os votos dos Conselheiros não juízes oriundos das carreiras do Ministério Público e da Advocacia e dos Conselheiros juízes (Ministros do STF e STJ), mas que têm origem profissional diversas da magistratura possuem uma tendência de julgar contra-magistrados nos processos administrativos em trâmite no CNJ. Conclui-se, também, que os votos de divergência do Corregedor Nacional de Justiça contra-magistrado é expressivamente maior se comparado ao voto pró-magistrado, proporção de $45,5 \%$ para $7,1 \%$.

Algumas decisões do CNJ demonstram usurpação de funções típicas do Poder Judiciário de decidir sobre algumas matérias. Da mesma forma, usurpa a função quando edita resolução sobre matérias de competência exclusiva do poder legislativo. 
O STF delineou os limites das atribuições do $\mathrm{CNJ}$, concluindo que não é permitido rever as decisões dos magistrados no âmbito do processo; está hierarquicamente subordinado ao STF; a competência está adstrita ao Poder Judiciário, não podendo interferir administrativamente nos poderes Executivo e Legislativo e; que o $\mathrm{CNJ}$ possui natureza administrativa interna, razão por que não pode rever nem modificar decisão judicial, isto é, não tem competência recursal.

O destino das decisões do $\mathrm{CNJ}$ está quase que automaticamente no poder de revisão do STF. Assim, a expectativa de segurança e transparência até então que se espera do CNJ perpassa por um antagonismo que aos poucos degenera no status de desconfiança.

No entanto, quando se trata de Adins o STF não tem emitido juízos definitivos sobre estas questões. Ao contrário, das 32 Adins o STF apreciou somente as liminares, tipicamente decididas de forma monocrática, adiado assim o momento da decisão final.

Numa concepção quantitativa os números do Múltiplo Supremo não computam uma quantidade significativa de recursos decorrentes de abusividades e ilegalidades das decisões do CNJ para apreciação do STF, margem de 458 entre 2005 a 2009. Observação distinta ocorre quanto à qualidade das decisões realizadas pelo $\mathrm{CNJ}$, pois de fato será reformada pelo STF, o que permite uma simples indagação, qual a efetividade do CNJ se suas decisões são reformadas pelo STF?

Não se trata, portanto, de proteger os direitos e garantias fundamentais dos juízes e servidores públicos, mas assegurar as atribuições elencadas pela $\mathrm{CR} / 88$ a cada órgão, caso que, por exemplo, o CNJ pode atuar/punir administrativamente, não desvirtuar-se ao modo de usurpar atribuições de outros poderes.

\section{REFERÊNCIAS}

BERMUDES, Sergio. A Reforma do Judiciário pela Emenda Constitucional $\mathbf{n}^{\mathbf{0}} 45$. Forense. p. 19-20, 2005 apud NERY JUNIOR, Nelson; NERY, Rosa Maria de Andrade. Constituição Federal Comentada e Legislação Constitucional. São Paulo: Revista dos Tribunais. 2006.

BRASIL. Constituição 1988. Constituição da República Federativa do Brasil, de 5 de outubro de 1988. Diário Oficial da União, 5 out. 1988

BRASIL. Emenda constitucional n. 45, de 30 de dezembro de 2004. Altera dispositivos dos arts. $5^{\circ}, 36,52,92,93,95,98,99,102,103,104,105,107,109,111,112,114,115,125,126$, 127, 128, 129, 134 e 168 da Constituição Federal, e acrescenta os arts. 103-A, 103B, 111-A e 130-A, e dá outras providências. Diário Oficial da União, Brasília, 30 dez. 2004. 
BRASIL, Supremo Tribunal Federal. Disponível em: http://www.stf.jus.br/arquivo/informativo/documento/informativo383.htm. Acesso: 08 de outubro de 2015.

BRASIL. Regimento Interno do Conselho Nacional de Justiça. DP: 05 abr. 2010. Disponível em:

$<$ http://www.cnj.jus.br/index.php?option=com_content\&view=article\&id=5110\&Itemid $=685>$. Acesso em: 10 out. 2015 .

CALMON, Eliana. Centro de Estudos Judiciários da Justiça Militar da União. 24/08/2012 - Disponível em: https://www.stm.jus.br/o-cejum/noticias/item/882-o-judiciario-era-umpoder-incontrolavel-diz-ministra-eliana-calmon. Acessado em: 14 de Outubro de 2015.

CARVAlHO FILHO, José dos Santos. Manual de Direito Administrativo. 27 ed. Rio de Janeiro: Lumen Juris, 2014.

CARVALHO, Matheus. Manual de Direito Administrativo. $2^{\text {a }}$ ed. Salvador: Jus Podivm, 2015.

CARVALHO, Ernani; LEITÃO, Natália. O Poder dos Juízes: Supremo Tribunal Federal e o Desenho Institucional do Conselho Nacional de Justiça. Revista de Sociologia e Política, v. 21, n. 45, março de 2013, p. 13-27.

DALLARI, Dalmo de Abreu. O Poder dos Juízes. 2a ed. São Paulo: Saraiva, 2002.

DIÁRIO da Câmara dos Deputados, terça-feira, 14 de dezembro de 1999. Diário do Congresso Nacional, editado pelo Senado Federal, Brasília-DF, 14 dezembro 1999. Ano LIV, Suplemento ao $\mathrm{n}^{\mathrm{o}} 209, \quad$ p. 01064. Disponível em: <http://imagem.camara.gov.br/Imagem/d/pdf/DCD0019991214SA2090000.PDF\#page=244>. Acesso em: ago. 2016.

DINAMARCO, Cândido Rangel. A Instrumentalidade do Processo. 14a ed. São Paulo: Malheiros, 2009.

DINAMARCO, Cândido Rangel. Nova era do processo civil. $3^{\text {a }}$ ed. São Paulo: Malheiros, 2009.

EDITORIAL: aposentadoria compulsória de juiz infrator é mais prêmio do que punição. Você concorda? Interativo Editorial. 24 de janeiro de 2013. Disponível em: http://wp.clicrbs.com.br/opiniaozh/2013/01/24/interativo-editorial-aposentadoriacompulsoria-de-juiz-infrator-e-mais-premio-do-que-punicao-voce-concorda/. Acessado em: 14 de Outubro de 2015.

FALCÃO, Joaquim; CERDEIRA, Pablo de Camargo; ARGUELHES, Diego Werneck. "I Relatório Supremo Em Números: O múltiplo supremo.” Fundação Getúlio Vargas, 2011.

FALCÃO, Joaquim; CERDEIRA, Pablo de Camargo; ARGUELHES, Diego Werneck. O Diálogo entre o CNJ e o Supremo. Ano 4, n. 16, p. 03, jan/mar, 2012. Disponível em: 
http://interessenacional.uol.com.br/index.php/edicoes-revista/o-dialogo-entre-o-cnj-e-osupremo/ Acesso: 16 de Outubro de 2015.

FRANCO, Ivan Candido da Silva de. COMO SÃO JULGADOS OS JUÍZES? Uma análise do controle disciplinar do Conselho Nacional de Justiça (2005-2013). São Paulo: Fundação Getúlio Vargas, 2015.

GAROUPA, Nuno; GINSBURG, Tom. Guardingtheguardians: Judicial Councilsand Judicial Independence. American Journal of Comparative Law, Chicago, novembro de 2008. Disponível em: 〈http://www.law.uchicago.edu/files/files/250-444_0.pdf>.

LENZA, Pedro. Direito Constitucional Esquematizado. 13ª ed. São Paulo: Saraiva, 2009.

MENDES, Gilmar. Organização do Poder Judiciário Brasileiro. p. 5. 2009. Disponível em: http://www.stf.jus.br/arquivo/cms/noticiaArtigoDiscurso/anexo/JudicBrasil.pdf. Acesso: 15 outubro de 2015.

SAMPAIO, José Adércio Leite. O Conselho Nacional de Justiça e a independência do Poder Judiciário. Belo Horizonte: Del Rey, 2007.

SOUZA, Gisele. CNJ abre processo disciplinar contra Luiz Zveiter, 2011. Disponível em: <http://www.cnj.jus.br/noticias/cnj/61405-cnj-prorroga-prazo-para-conclusao-de-pad-contraluiz-zveiter-desembargador-do-tjrj>. Acesso em: 30 de ago. 2016. 